\title{
Studi Fenomenologi Pengalaman Penderita HIV dan AIDS Tanpa Pasangan Hidup dalam Memenuhi Kebutuhan Seksual di Lembaga Kasih Indonesia Tahun 2013
}

\author{
Salamah Thomasitha Batubara ${ }^{1}$, Maisaroh $^{2}$ \\ ${ }^{1}$ STIKES Bani Saleh \\ 2. STIKES Bani Saleh \\ ${ }^{1}$ salamah@stikesbanisaleh.ac.id \\ ${ }^{2}$ Maisaroh_sri@yahoo.com
}

\begin{abstract}
This phenomenological study analyzes the experiences of HIV and AIDS patients who live as singles cal in fulfilling the sexual needs. The analytical tool used is the phenomenological design with in depth interviews and observasional study. Data sampling is derived from in-depth interviews, and the verbatim result is revealed through the Colaizzi methodology. Subjects of the study focus on past incidents that caused the HIV infection, emotional experience after infection, personal observation when sexual needs arised, ways to fulfill the related needs, common obstructions in the process of fulfillment, and the expectations of HIV and AIDS patients who live as a singles. To fulfill the sexual needs, the HIV and AIDS patients who live as singles refer to two different options, which are having sexual intercourse with condom and masturbation. This study recommends the necessity of condom in the sexual intercourse for HIV and AIDS patients, however the effectiveness of condom used were not focused in this research.
\end{abstract}

Keywords : sexual needs, HIV and AIDS patients, single

\begin{abstract}
Abstrak - Abstrak dibuat sebagai ringkasan singkat atas keseluruhan isi artikel yang disajikan dalam satu paragraph dan Panjang tidak lebih dari 200 Kata. Abstrak ditulis secara jelas, padat dan menggunakan kalimat yang efektif. Abstrak harus dapat membantu pembaca memahami pokok-pokok penting dari artikel, sehingga dapat memberi gambaran umum yang jelas atas isi artikel. Penulisan abstrak terdiri dari empat pokok utama yang disusun secara berurutan. Pokok pertama abstrak menjelaskan tujuan utama dan persoalan penelitian yang dibahas. Pokok kedua menjelaskan metode penelitian yang dibahas secara umum. Pokok ketiga menjelaskan temuan utama atau hasil dari analisis yang dibuat. Pokok keempat menguraikan secara singkat interpretasi atas hasil serta simpulan dari penelitian. Abstrak tidak diperkenankan menjelaskan latar belakang secara ekstensif, memuat kutipan, memuat singkatan atau istilah yang tidak dikenal secara umum, memuat angka-angka statistik, tabel, gambar atau rujukan ke table/gambar tersebut. Abstrak juga tidak diperkenankan menyajikan informasi yang tidak dibahas dalam artikel, serta mendefinisikan suatu istilah. Abstrak disajikan baik dalam Bahasa Indonesia maupun Bahasa Inggris.
\end{abstract}

Kata kunci : kebutuhan seksual, pasien HIV dan Aids, single

\section{A. PENDAHULUAN}

Seks bebas sering berujung pada penyakit menular seksual, termasuk HIV dan AIDS. Psikolog Baby Jim Aditya, pernah memaparkan sebagian besar pengidap HIV dan AIDS berada di usia produktif, yakni 20 - 29 tahun. Hal ini karena kurangnya pengetahuan mereka yang sudah terlanjur bebas dan berisiko tidak diselaraskan pengetahuan penggunaan alat kontrasepsi, seperti kondom karena bentroknya kampanye kondom dengan nilai budaya. (Surabaya Post, 08 April 2013).
Data WHO saat ini menyatakan bahwa sekitar 36.100.000 penduduk dunia terinfeksi HIV dan AIDS dimana enam juta kasus terdapat di Asia Tenggara (BKKBN online, 2006). Ditjen PPM\&PL Depkes RI menyatakan, dari Juli 1987 sampai dengan September 2007 pengidap HIV dan kasus AIDS sebanyak 16.288 orang dengan kematian 2.287 (Haroen H, dkk Jurnal Ners vol 10 No. XV111 Maret-September 2008). Indonesia adalah salah satu Negara di Asia dengan epidemik HIV yang 
berkembang paling cepat (UNAIDS, 2008 dalam Mardhiati R, 2011).

Secara komulatif sampai dengan Desember 2010, Kementerian Kesehatan (Kemenkes RI, 2011) melaporkan ada 24.131 jumlah kasus AIDS dari 300 Kabupaten/kota dan 32 provinsi yang melapor. Hingga akhir tahun 2009 diperkirakan di Indonesia terdapat di Indonesia186.257 orang yang berusia antara 15-49 tahun yang hidup dengan HIV dan AIDS (Odha) dan tersebar di seluruh 33 provinsi. Berdasarkan pemodelan pada tahun 2014 jumlah Odha akan mencapai hampir tiga kali lipat menjadi 541.700 orang, Di Indonesia, HIV dan AIDS pertama kali ditemukan di propinsi Bali pada tahun1987. Hingga saat ini HIV AIDS sudah ditemukan menyebar di 386 kabupaten /kota di seluruh provinsi di Indonesia (Ditjen PP\&PL, Kemenkes Ri,2014)

Penularan HIV dan AIDS pada perempuan sebagian besar terjadi melalui hubungan seksual dan sebagian besar berada pada usia reproduksi. Perempuan yang tertular HIV lewat narkoba suntik datang dengan imunitas yang lebih rendah daripada yang tertular lewat hubungan seksual.Hal tersebut didapatkan dari hasil catatan medis perempuan dengan HIV dan AIDS di poliklinik Kelompok Studi Khusus (Pokdisus) RSUPN Dr. Cipto mangunkusumo Jakarta dari bulan Januari sampai Juli 2006. Didapatkan 309 perempuan dengan HIV dan AIDS dan sebagian besar $(73,5 \%)$ berusia antara 20-30 tahun. Risiko penularan didapatkan $77,02 \%$ lewat transmisi seksual, $11,33 \%$ lewat narkoba suntik saja, dan 11,65\% lewat narkoba suntik dan hubungan seksual. (Pertemuan Ilmiah Tahunan Ilmu Penyakit Dalam 2006, Departemen Ilmu Penyakit Dalam Fakultas Kedokteran Universitas Indonesia).
Penggunaan kondom pada penderita HIV dan AIDS dalam melakukan hubungan seksual sering diabaikan hal ini sesuai dengan hasil penelitian dari KPA kerjasama dengan Australia Indonesia Partnership, dalam survey perilaku peserta penasun dalam program Harm Reduction di DKI Jakarta, Jawa Barat, dan Bali. Hasilnya adalah kemampuan untuk meningkatkan penggunaan kondom masih terbatas, namun strategi-strategi untuk komunikasi yang efektif untuk perubahan perilaku telah dikembangkan sebagai bagian dari program pelatihan untuk staf puskesmas dan LSM dalam kesehatan seksual dan reproduksi untuk mendukung prilaku seks yang lebih aman (KPA, 2009).

\section{B. METODE PENELITIAN}

Penelitian ini menggunakan metode kualitatif dengan pendekatan fenomenologi untuk menggali pengalaman atau memperoleh jawaban yang mendalam tentang pendapat dan perasaan seorang penderita HIV dan AIDS tanpa pasangan hidup dalam memenuhi kebutuhan seksnya. Penelitian kualitatif ini menggunakan metode wawancara terbuka untuk menelaah dan memahami sikap, pandangan, perasaan, dan perilaku individu atau sekelompok orang. Intrumen utama adalah peneliti sendiri, alat bantu lain sebagai pendukung proses pengumpulan data adalah pedoman wawancara (interview guide, catatan lapangan (fields notes) dan tape recorder).

Penelitian ini melibatkan peneliti sebagai alat dalam mengidentifikasi pengertian atau relevansi fenomena tertentu terhadap individu. Selama penelitian, peneliti mencari gambaran mengenai pengalaman yang ada pada penderita HIV dan AIDS tanpa pasangan hidup dalam memenuhi kebutuhan 
seksnya, dan peneliti memahami sepenuhnya pengalaman informan untuk mempermudah penelitian.

Dalam penelitian ini informan adalah penderita HIV dan AIDS tanpa pasangan hidup di Yayasan Lembaga Kasih Indonesia yang sudah mendapat ijin dari direktur Yayasan LKI yang dipilih menggunakan metode purposive sampling (Moleong, 2011). Meskipun penelitian terbilang cukup lama yakni September -April 2013, penelitian serupa dengan metodologi yang sama belum ditemukan setelahnya. Dengan etika penelitian yang memenuhi empat prinsip utama yaitu: a. Respon for human dignity b. Respect for privacy and contidentiality c. Respect for justice and inclusiveness d. Balancing harms and benefits. (Milton, 1999; Loiselle, Profetto-McGrath, Polit \& Beck, 2004 dalam Yurisa W, 2008).

Analisis Data. Analisa data pada penelitian ini menggunakan metode interpretasi data sembilan langkah menurut Collaizi Speziale, et al, 2010 dengan tahap: a. Mendeskripsikan fenomena yang diteliti, b. Mengumpulkan deskripsi fenomena melalui pendapat informan, c. Membaca seluruh deskripsi fenomena, d. Membaca kembali transkrip hasil wawancara dan mengutip pernyataan bermakna, e. Menguraikan arti yang ada dalam pernyataan-pernyataan signifikan, $f$. Mengorganisir kumpulan-kumpulan makna yang dirumuskan dalam kelompok tema, g. Menuliskan deskripsi yang lengkap, h. Menuliskan deskripsi yang lengkap, i. Menemui informan untuk validasi deskripsi hasil analisis, $\mathrm{j}$. Menggabungkan data hasil validasi ke dalam deskripsi hasil analisis.

\section{HASIL DAN PEMBAHASAN}

Karakteristik informan pada penelitian fenomenologi: pengalaman penderita
HIV dan AIDS tanpa pasangan hidup di Lembaga Kasih Indonesia tahun 2013 adalah sebagai berikut:

\begin{tabular}{|c|c|c|c|c|c|c|c|}
\hline No. & Variabel & | 1 & 12 & 13 & 14 & 15 & 16 \\
\hline 1. & $\begin{array}{l}\text { Umur } \\
\text { (thn) }\end{array}$ & 36 & $\begin{array}{c}31 \\
\text { thn }\end{array}$ & 28 thn 3 & 33 thn & 27 thn & 22 thn \\
\hline 2. & $\begin{array}{c}\text { Jumlah } \\
\text { anak }\end{array}$ & 1 & - & 2 & 2 & 2 & - \\
\hline 3. & Pendidikan & SMA & SMA & SMA & SMA & $\begin{array}{c}\text { Diploma } \\
2 \\
\end{array}$ & SMA \\
\hline 4. & $\begin{array}{l}\text { Lama } \\
\text { tanpa } \\
\text { pasangan } \\
\text { hidup }\end{array}$ & 6 thn & 3 thn & 22 bln & 3thn & 2 thn & 2 thn \\
\hline
\end{tabular}

Penelitian ini menghasilkan 7 tema yang menjelaskan permasalahan penelitian. Penentuan tema tersebut terbentuk dari proses analisis dari keenam informan. Tema yang diperoleh tentang pengalaman penderita HIV dan AIDS tanpa pasangan hidup dalam memenuhi kebutuhan seks adalah sebagai berikut:

1. Penyebab terinfeksi HIV dan AIDS

Kata kunci Kategori Sub Tema Tema
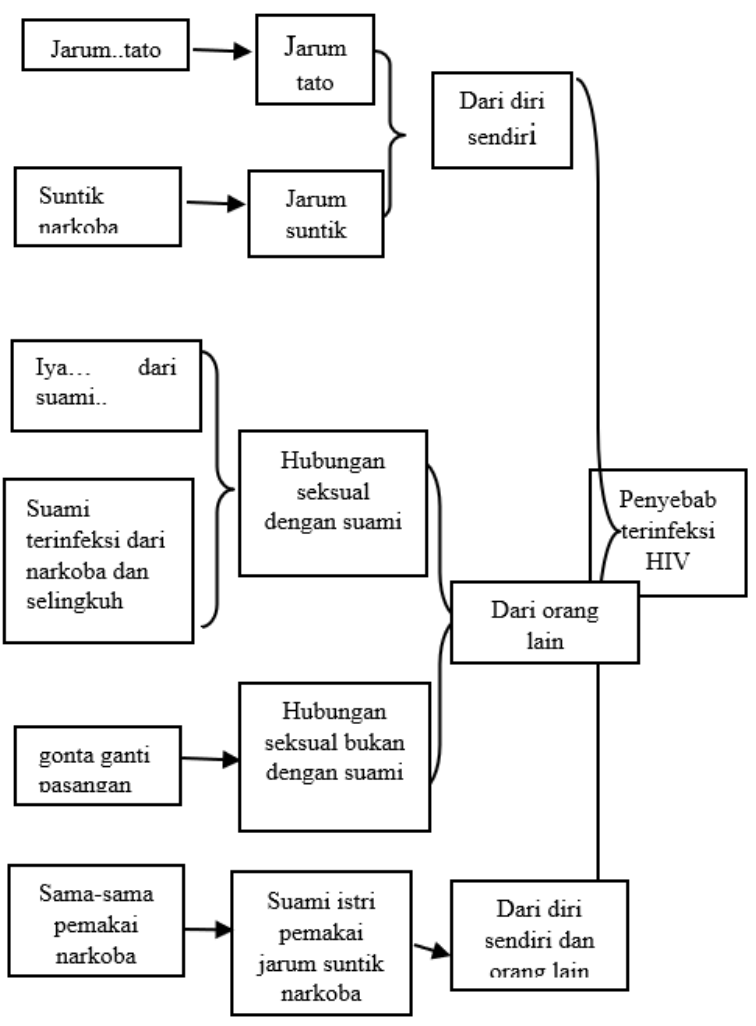
Satu dari enam informan menyatakan bahwa penyebab terinfeksi HIV adalah dari tato, dua dari enam informan mengemukakan bahwa dirinya terinfeksi HIV dari hubungan seksual dengan suaminya, hanya satu informan yang menyatakan bahwa dirinya terinfeksi karena berhubungan dengan lebih dari satu pasangan, dan dua lainnya mengungkapkan bahwa dirinya terinfeksi HIV dan AIDS akibat dari baik dirinya sendiri maupun suaminya sama - sama beresiko terhadap infeksi HIV.

2. Perasaan setelah terinfeksi

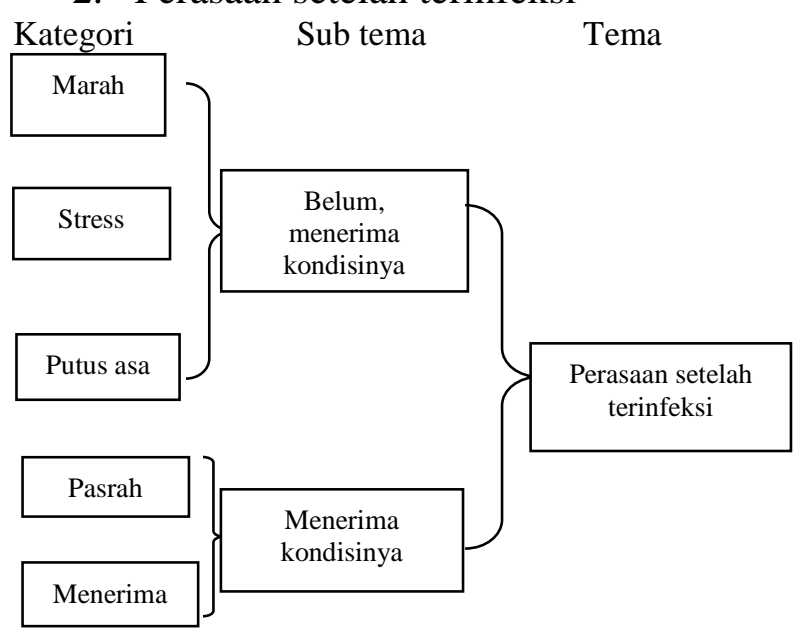

Tiga dari enam informan menyatakan dirinya belum bisa menerima kondisinya yaitu dengan marah, stress dan putus asa, tiga dari enam informan menyatakan pasrah dan menerima saat pertama kali tau menderita HIV dan AIDS.

Tertuang dalam narasi “...syok, kaget, bingung, yaa.. takut, pasrah, semuanya, bahkan mungkin hampir bunuh diri.. ..Eee.. iya..Semuanya...Dengan cara gantung diri.. hampir-hampir saya gantung diri.. hampir putus asa, kondisi waktu itu masih drops, masih sakit, minum obat masih sekitar sehari 12 butir....."(I2).

3. Perasaan saat kebutuhan seks datang

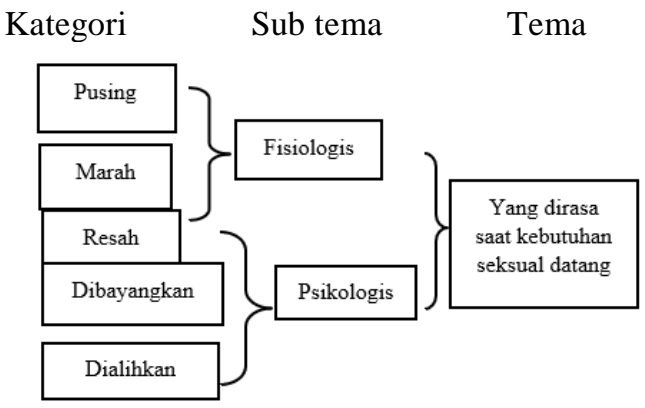

Tiga dari enam informan menyatakan pusing ketika kebutuhan seksual itu datang, satu dari enam informan menyatakan marah apabila timbul perasaan seks itu datang, tiga dari enam informan mengungkapkan apabila kebutuhan seks datang adalah resah, membayangkan dan dialihkan.

Tertuang dalam narasi “..Pusing...pusingnya beda kalo pas kita lagi pengen...Pusing kalo pengen...Maksudnya pengen gitu ... pusing kita mau... karena kita kan udah dewasa gitu, jadi tau.. kalo ada hasrat seperti itu muncul sendiri keinginan itu...." (I 2).

4. Cara pemenuhan kebutuhan seksual pada penderita HIV dan AIDS tanpa pasangan hidup

Kategori Sub tema Tema

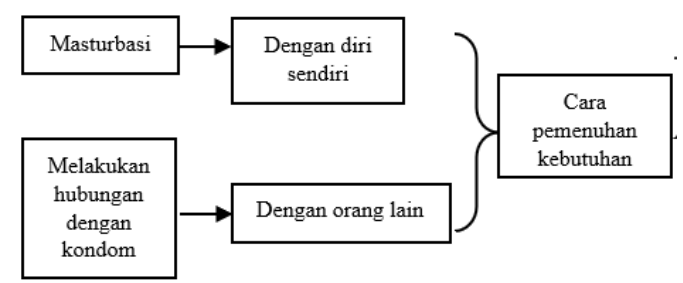

Dua dari enam informan mengungkapkan bahwa cara pemenuhan kebutuhan seksual yaitu dengan masturbasi, lima dari enam informan mengungkapkan bahwa cara dalam memenuhi kebutuhan seksual adalah dengan melakukan hubungan seks dengan menggunakan kondom.

Tertuang dalam narasi “...trus yang kedua sama duda jadi kita tidak mau berbohong kadang-kadang kita sebulan sekali sebulan 2 kali kita ke hotel tapi 
dari LKI ada kondom perempuan ada kondom laki-laki klo mau tinggal ambil aja.. gratis ..nggak bayar..." (I 2).

5. Upaya yang dilakukan saat kebutuhan seks datang

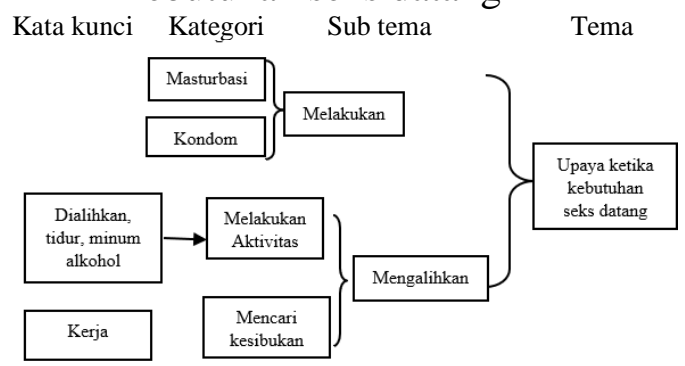

Tiga dari enam informan lebih memilih mengalihkan ke hal lain dengan melakukan aktivitas seperti menonton TV dan tidur, dua dari enam informan mengungkapkan ketika kebutuhan seks datang, upaya yang dilakukan adalah dengan mencari kesibukan.

Tertuang dalam narasi “... $a k u$ disibukkan dengan tugas yang lain, aku juga budhist di dunia maya. ada komunitas di facebook eee odha gitu kan yang kadang-kadang tidak

pengen didampingin sama LSM gitu... akirnya aku disibukkan dengan kerjaan.... laporan yang harus aku kerjain ........." (I 4).

6. Hambatan dalam memenuhi kebutuhan seks

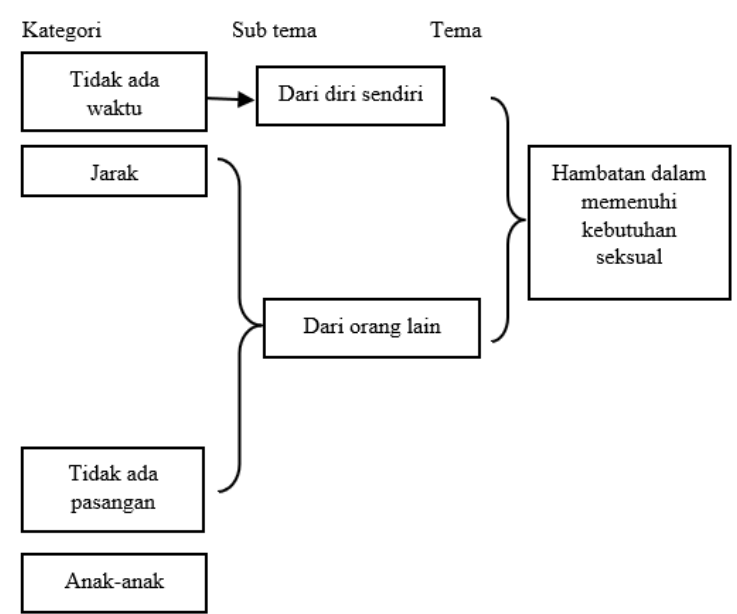

Satu dari enam informan menyatakan bahwa tidak ada waktu dikarenakan sibuk bekerja menjadi faktor yang menghambat dalam memenuhi kebutuhan seksual, tiga dari enam informan mengungkapkan bahwa tidak adanya pasangan menjadi hambatan dalam memenuhi kebutuhan seksual, satu dari enam informan mengungkapkan bahwa anak-anak menjadi hambatan dalam memenuhi kebutuhna seksual, satu dari enam informan menganggap jarak menjadi hambatan dalam memenuhi kebutuhan seksual.

Tertuang dalam narasi “....Ya hambatannya ya itu karena nggak ada pasangannya hahaha baru selama ini aja kan sebulan ini aja karena baru ketemu... dia juga baru ketemu kita kayak gitu ya enggaklah...." (I 3).

7. Harapan masa depan

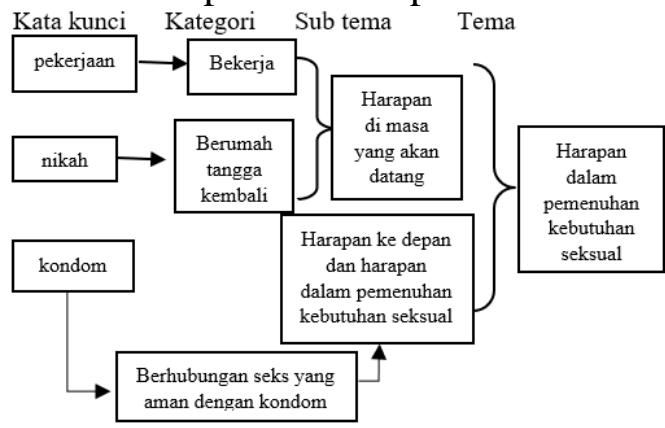

Dua dari enam informan mengemukakan ingin bekerja dan hidup lebih lama lagi, empat dari enam informan mengemukakan bahwa ingin berumah tangga kembali, semua informan mengemukakan bahwa harapan ke depan dalam berhubungan seksual adalah dengan menggunakan kondom. Tertuang dalam narasi “...Tetap pake (kondom)...Saya berusaha sebisa mungkin selalu pake, emang susah sih mba kalau sama-sama positif HIV mungkin bisa menerima jadi samasama mau pake tapi kalau hanya saya yang positif ya kembali lagi kesitu pemicu terjadi lagi kan rasa takut di saya nya rasa kesalahan saya nya kalau 
ngga make..padahal maksud kita kan baik tapi masalahnya kita membuka status..." (I 6).

\section{Interpretasi Hasil Penelitian -}

Penelitian ini menghasilkan 7 tema dari analisis sub tema. Adapun tema yang diperoleh dari penelitian ini adalah 1) Penyebab terinfeksi HIV 2) Perasaan setelah terinfeksi 3) Yang dirasa saat kebutuhan seksual datang 4) Cara pemenuhan kebutuhan seksual 5) Upaya ketika kebutuhan seks datang6) Hambatan dalam memenuhi kebutuhan seksual 7) Harapan ke depan dan harapan dalam pemenuhan kebutuhan seksual.

\section{Penyebab Terinfeksi HIV.}

Penyebab terinfeksi HIV didapatkan dalam dua sub tema yaitu dari diri sendiri yang meliputi tatto dan narkoba suntik dan dari orang lain yang meliputi hubungan seksual dengan suami dan gonta ganti pasangan, dimana sesuai dengan tujuan khusus yaitu teridentifikasinya gambaran pengalaman penderita HIV dan AIDS. Hasil penelitian yang berkaitan dengan penyebab terinfeksi HIV didapatkan bahwa penyebab terinfeksi HIV adalah tato dan narkoba suntik. Ungkapan informan dapat diperkuat oleh pendapat dr. Husein Pancratius Tahun 2009 (Antara, 2010), bahwa untuk penanggulangan HIV dan AIDS dan Penyalah gunaan Narkotika yang menyatakan bahwa telah dijumpai ada kasus HIV dan AIDS pada populasi dengan resiko rendah seperti ibu rumah tangga dan anak-anak dan pola penularan tidak hanya melalui hubungan seks tetapi juga melalui penggunaan narkotika suntik. Senada dengan konsep yang menyatakan bahwa cara penularan HIV melalui pemakaian alat kesehatan yang tidak steril seperti alat pemeriksaan kandungan meliputi speculum, terakulum, dan alat-alat lain yang menyentuh darah, cairan vagina, atau air mani yang terinfeksi HIV. Selain itu penularan HIV dapat melalui alat-alat untuk menorah kulit seperti jarum, pisau, silet, menyunat seseorang, membuat tato, memotong rambut, serta menggunakan jarum suntik secara bergantian (Nasution, Z, 2008).

Hasil penelitian yang didapatkan dari pengalaman penderita HIV didapatkan penyebab terinfeksi HIV adalah penularan dari hubungan seksual dengan suami atau pasangan hidupnya serta adanya perilaku gonta ganti pasangan seks. Hasil penelitian tersebut terbukti sesuai dengan apa yang dituturkan Tuti Parwati Merati, selaku Ketua Pokja CST Komisi Penanggulangan AIDS Bali, 2013 (Republika, 2013) yang menyatakan pada banyak kasus, sering ditemukan seorang istri yang hanya diam di rumah dan pada saat gadis tidak melakukan perilaku berisiko ternyata terkena HIV. Mereka tertular dari suaminya yang melakukan hubungan seksual bergonta-ganti pasangan.

Hasil penelitian seiring dengan konsep perilaku resiko tinggi tertular AIDS adalah perilaku seseorang yang berbahaya, meliputi perpindahan air mani yang dilakukan melalui aktivitas seksual-lewat vaginal, oral atau analpersetubuhan. Ataupun aktivitas yang melibatkan perpindahan transfusi darah, dapat melalui aktifitas seksual, transfusi darah atau berbagai jarum suntik dengan orang lain, Curtis dkk, Seligson \& Peterson, 1992 (Anurmalasari, dkk, 2010). Penularan HIV dapat terjadi pada perilaku individu, seperti penggunaan jarum suntik yang tidak steril misalnya dalam mengkonsumsi narkoba dan hubungan seks yang tidak aman, Ogden, 2007 (Arriza, 2011).

\section{Perasaan setelah terinfeksi}

Hasil penelitian mengungkapkan bahwa perasaan setelah terinfeksi meliputi 1) marah 2) stress 3) putus asa 4) pasrah 5) menerima. Hasil penelitian diatas sesuai 
dengan konsep yang menyatakan Respons Psikologis (penerimaan diri) terhadap penyakit Kubler 'Ross 1974 (Nursalam, 2007) menguraikan lima tahap reaksi emosi seseorang terhadap penyakit, yaitu:

a. Pengingkaran (denial). Pada tahap pertama informan menunjukkan karakteristik perilaku pengingkaran, mereka gagal memahami dan mengalami makna rasional dan dampak emosional dari diagnosa. Pengingkaran ini dapat disebabkan karena ketidaktahuan informan terhadap sakitnya atau sudah mengetahuinya dan mengancam dirinya. Pengingkaran diri yang mencolok tampak menimbulkan kecemasan, pengingkaran ini merupakan buffer untuk menerima kenyataan yang sebenarnya. Pengingkaran biasanya bersifat sementara dan segera berubah menjadi fase lain dalam menghadapi kenyataan, Achir Yani, 1999 (Nursalam, 2007).

b. Kemarahan (anger). Hasil penelitian mengungkapkan bahwa pada saat pertama kali penderita HIV mengetahui statusnya adalah marah. Hasil tersebut diperkuat dengan adanya konsep yang menyebutkan bahwa apabila pengingkaran tidak dapat dipertahankan lagi, maka fase pertama berubah menjadi kemarahan. Perilaku pasien secara karakteristik dihubungkan dengan marah dan rasa bersalah. Pasien akan mengalihkan kemarahan kepada sesuatu yang ada disekitarnya. Biasanya kemarahan diarahkan pada dirinya sendiri dan timbul penyesalan. Jika keluarga mengunjungi maka menunjukkan sikap menolak, yang mengakibatkan keluarga segan untuk datang, hal ini akan menyebabkan bentuk keagresipan, Hudak \& Gallo, 1996 (Nursalam, 2007).

c. Sikap tawar menawar (bargaining). Setelah marah-marah berlalu, pasien akan berfikir dan merasakan bahwa protesnya tidak ada artinya. Mulai timbul rasa bersalahnya dan mulai membina hubungan dengan Tuhan, meminta dan berjanji merupakan ciri yang jelas yaitu pasien menyanggupi akan menjadi lebih baik bila terjadi sesuatu yang menimpanya atau berjanji lain jika dia dapat sembuh, Achir yani, 1999 (Nursalam, 2007).

d. Depresi. Selama fase ini pasien sedih/berkabung mengesampingkan marah dan pertahanannya serta mulai mengatasi kehilangan secara konstruktif. Tingkat emosional adalah kesedihan, tidak berdaya, tidak ada harapan, bersalah, penyesalan yang dalam, kesepian dan waktu untuk menangis berguna pada saat ini. Perilaku fase ini termasuk mengatakan ketakutan akan masa depan, intensitas depresi tergantung pada makna dan beratnya penyakit, Netty, 1999 (Nursalam, 2007) e. Penerimaan dan partisipasi. Sesuai dengan berlalunya waktu dan pasien beradaptasi, kepedihan dari kesabaran yang menyakitkan berkurang dan bergerak menuju identifikasi sebagai seseorang yang keterbatasan karena penyakitnya dan sebagai seorang cacat. Pasien mampu bergantung pada orang lain jika perlu dan tidak membutuhkan dorongan melebihi daya tahannya atau terlalu memaksakan keterbatasan atau ketidakadekuatan, Hudak \& Gallo, 1996 (Nursalam, 2007). Hasil penelitian diatas sesuai dengan konsep yang menyebutkan bahwa HIV dapat menyerang siapa saja, orang yang terinfeksi HIV akan menjadi pembawa dan penular virus HIV selama hidupnya, orang dengan HIV dan AIDS masih mendapat stigma dan perlakuan diskriminasi oleh masyarakat. Mengidap HIV dan AIDS di Indonesia dianggap aib, sehingga dapat menyebabkan tekanan psikologis terutama pada penderitanya maupun pada keluarga dan lingkungan disekeliling penderita 
(Nursalam \& Kurniawati, 2007 dalam Anurmalasari, dkk. 2010).

Ketakutan tertular AIDS karena penyakit tersebut sering dikaitkan dengan homoseksual dan pemakaian narkoba di Negara yang sedang berkembang, penderita AIDS dan keluarganya beserta juga pacarnya sering merasa stigmatis (Flaskerud dkk, Sarafino, 1994 dalam Anurmalasari, dkk, 2010).

Pengalaman mengalami suatu penyakit akan membangkitkan berbagai perasaan dan reaksi stress, frustasi, kecemasan, kemarahan, penyangkalan, rasa malu, berduka, dan ketidakpastian dengan adaptasi terhadap penyakit (Nursalam \& Kurniawati, 2007 dalam Anurmalasari, dkk, 2010).

Yang dirasa saat kebutuhan seksual datang Hasil dari penelitian didapatkan bahwa saat kebutuhan seksual datang yang dirasakan oleh para informan adalah pusing, marah, dan resah, sedangkan yang lain didapatkan cukup dialihkan dan dibayangkan saja ketika kebutuhan seksual itu timbul. Hal tersebut diperkuat apa yang diungkapkan oleh Psikolog Klinis dan Segsolog, Baby Jim Aditya (Tempo.com, 2012).

Cara pemenuhan kebutuhan seksual.

Hasil penelitian mengungkapkan bahwa cara pemenuhan kebutuhan seksual meliputi 1) masturbasi dan 2) melakukan hubungan dengan kondom. Informan memilih masturbasi karena tidak ada dampak menularkan virusnya kepada siapapun, hal ini diperkuat dengan penelitain yang menyatakan didapatkan informasi bahwa mereka melakukan praktek-praktek seksual dalam bentuk masturbasi sebanyak 78\% (Wahyuni, 2004 dalam Siregar N dkk, 2012).

Informan memilih menggunakan kondom dengan alasan supaya tidak menularkan kepada pasangan seksnya. Hasil penelitian diatas diperkuat oleh penelitian yanga menyatakan upaya lain yang juga dilakukan oleh informan untuk mengatasi hambatan penggunaan kondom disebutnya sebagai strategi jitu yakni kemampuan untuk menjalin komunikasi pada pasangan dengan membujuk dan meyakinkan pasangan terhadap konsekuensi jika tidak menggunakan kondom (Ridwan E, dkk, 2013).

\section{Upaya ketika kebutuhan seksual datang.}

Hasil penelitian yang terkait dengan upaya ketika kebutuhan seksual datang adalah dengan melakukan hubungan seksual dengan menggunakan kondom yang didapatkan dari personal, dalam hal ini adalah anggota staf yayasan LKI. Dari staf dikatakan bahwa selain mencegah kehamilan menggunakan kondom saat berhubungn seks juga mencegah tranfusi silang virus HIV. Selain menggunakan kondom upaya untuk memenuhi ketika kebutuhan seksual datang adalah dengan masturbasi. Hal ini dilakukan oleh dampingan yayasan LKI.

\section{Hambatan dalam memenuhi kebutuhan seksual.}

Hasil penelitian mengungkapkan bahwa ada yang mempunyai hambatan dalam memenuhi kebutuhan seksual, hambatan tersebut bisa datang dari diri sendiri dan dari orang lain. Hal ini didapatkan baik dari staf yayasan maupun dari dampingan yayasan. Hambatan dari sendiri adalah karena tidak adanya waktu ketika kebutuhan seksual itu datang dikarenakan kesibukan. Hambatan dari orang lain dalam hasil penelitian ini terungkap bahwa hambatan yang mereka alami dari faktor orang lain adalah karena tidak adanya pasangan seks, jarak, serta anakanak.

Harapan kedepan dan harapan yang
berhubungan dengan kebutuhan
seksual.


Hasil penelitian mengungkapkan bahwa harapan untuk masa depan adalah bekerja, hidup lebih lama lagi, serta menginginkan menikah kembali. Sedangkan untuk harapan yang berhubungan dengan kebutuhan seksual adalah melakukan hubungan seks dengan cara yang aman yaitu menggunakan kondom. Hasil penelitian diatas diperkuat dengan hasil penelitian yang dilakukan oleh Lembaga Penelitian Dan Pengembangan Universitas Muhammadiyah Prof. Dr. Hamka (Mardhiati R, 2011) yang menyatakan sebagian besar penderita HIV dan AIDS memiliki rencana untuk menikah walaupun penderita HIV dan AIDS tersebut memiliki status janda atau duda (pasangan meninggal karena HIV). Rencana untuk menikah tetap dimiliki oleh penderita HIV yang cenderung mencari pasangan yang juga sesama penderita HIV. Penelitian yang dilakukan pada penderita HIV dan AIDS di Unit Layanan Terpadu RSCM Jakarta tahun 2011, menunjukkan terdapat $60 \%$ penderita HIV dan AIDS yang tetap menginginkan hidup berkeluarga dan $74 \%$ diantaranya menginginkan menikah dengan orang yang tidak terinfeksi HIV, serta $50 \%$ tetap berkeinginan memiliki anak(Hastuti, 2011 dalam Ridwan E, dkk, 2013).

Hasil penelitian seiring dengan penelitian yang dilakukan oleh Tsevat, dkk 1999 (Arriza, dkk. 2011), penderita HIV dan AIDS juga memiliki keinginan yang besar untuk terus hidup, dan memiliki harapan bahwa kehidupan mereka lebih baik daripada kehidupan mereka sebelumnya.

\section{KESIMPULAN DAN SARAN}

Tujuh tema dalam penelitian ini yaitu penyebab terinfeksi HIV dan AIDS, perasaan saat pertama mengetahui terinfeksi, yang dirasa saat kebutuhan seksual datang, cara, upaya, hambatan dalam pemenuhan kebutuhan seksual, serta harapan ke depan penderita HIV dan AIDS tanpa pasangan hidup. Penyebab terinfeksi HIV dan AIDS adalah dari diri penderita sendiri yaitu jarum tato dan jarum suntik narkoba. Penyebab terinfeksi yang lain adalah dari orang lain dalam hal ini melakukan hubungan seksual dengan suami yang telah terinfeksi terlebih dahulu. Perasaan penderita HIV dan AIDS saat pertama kali terdiagnosis adalah dari yang berlaku marah, stress, putus asa, pasrah, yang pada akhirnya bisa menerima kondisinya. Informan merasakan pada saat kebutuhan seksual datang adalah pusing, marah, resah, namun ada yang cukup dengan membayangkan dan mengalihkan saja. Selain pengalamannya memenuhi kebutuhan seksual melalui dua cara, yang pertama yaitu masturbasi dengan memegang kemaluan sendiri sehingga bisa merasakan kepuasan meskipun tanpa berhubungan badan. Cara yang kedua adalah melakukan hubungaan seksual dengan menggunakan kondom supaya tidak terjadi transfer silang virus HIV.

Upaya yang dilakukan penderita HIV dan AIDS tanpa pasangan hidup dalam memenuhi kebutuhan seksual adalah menahan diri dan mengalihkan ke hal lain. Hal yang bisa dilakukan untuk mengalihkan adalah dengan menonton TV, sholat, wiridhan, melakukan aktifitas sehari-hari serta bekerja. Hambatan dalam memenuhi kebutuhan seksual yan dialami penderita HIV dan AIDS tanpa psangan hidup dalam memenuhi kebutuhan seksual adalah tidak adanya pasangan, kalaupun ada pasangan jaraknya jauh, tidak ada waktu, serta keberadaan anak-anak yang masih kecil-kecil. Harapan ke depan yang diinginkan penderita HIV dan AIDS adalah menikah kembali dan 
menggunakan kondom dalam melakukan hubungan seksual.

\section{DAFTAR PUSTAKA}

Antara. (2010). Penularan HIV / AIDS pada Titik Kritis.15 Februari 2010.http://www.aidsindonesia.o r.id

Anurmalasari, dkk. (2010). Hubungan Antara Pemahaman Tentang HIV / AIDS dengan Kecemasan Tertular HIV / AIDS pada WPS (Wanita Penjaja Seks). 21 Mei 2010. Thesis Universitas Diponegoro: tidak dipublikasikan

Arriza, dkk. (2011). Memahami Rekonstruksi Kebahagiaan Pada Orang dengan HIV / AIDS (ODHA). Jurnal Psikologi Undip (Vol. 10 No. 2 Oktober 2011)

Compact-female (2011). Modul Pelatihan Deteksi Dini Pencegahan dan Penanganan HIV\&AIDS Pada Perempuan untuk Perawat Kesehatan Masyarakat. Bandung: Dipublikasikan dalam kalangan terbatas.

Danim, S. (2003). Riset Keperawatan: Sejarah dan Metodologi. Jakarta: EGC

Djoerban, Z. (1999). Membidik AIDS Ikhtiar Memahami HIV dan ODHA. Galang Press: Yogyakarta.

Haroen H, dkk (2008). Kualitas Hidup wanita Penderita AIDS dan Wanita Pasangan Penderita AIDS di Kabupaten Bandung Barat.Jurnal Ners Indonesia (volume 10 No. XV111).

Hidayat, A. (2009). Pengantar Kebutuhan Dasar Manusia Aplikasi Konsep dan Proses Keperawatan. Jakarta: Salemba Medika

Komisi Penanggulangan Aids (KPA) (2009). Peserta Penasun dalam
Program Harm Reduction

Bekerjasama dengan Dinas Kesehatan, KPAP dan LSM. Jakarta. Tidak dipublikasikan.

Komisi Penanggulangan Aids (KPA) (2012). Survey Klien: Perilaku dan Kepuasan Layanan 2012 pada Penasun Klien Program Harm Reduction di Bali, Banten, Jakarta, Jateng, Jatim, Jabar dan Yogyakarta. Jakarta. Tidak dipublikasikan.

Mardhiati R, dkk (2011). Penelitian Peran Dukungan Sebaya Terhadpa Peningkatan Mutu Hidup ODHA di Indonesia Tahun 2011. Lembaga Penelitian Dan Pengembangan Universitas Muhammadiyah Prof. Dr. Hamka.

Marilyn F. M (2010). BukuAjar Keperawatan Keluarga : Riset, Teori dan Praktik. Jakarta: EGC.

Minarningtyas A, (2011). Study Fenomenologi: Pengalaman Kepala Ruangan dalam Menjalankan Fungsi Pengarahan di Ruang Rawat Inap RSUD Kota Bekasi. Tesis FIK UI: tidak dipublikasikan

Moleong (2011). Metodologi penelitian Kualitatif. Edisi Revisi. Bandung: PT Remaja Rosdakarya.

Nasution Z, (2008). Gambaran Karakteristik Pengetahuan Penderita Penyakit HIV/AIDS di Rumah Sakit Umum Pusat Haji Adam Malik Medan tahun 2008. Jurnal Darma Agung

Nursalam, dkk. (2007). Asuhan Keperawatan Pada Pasien Terinfeksi HIV. Jakarta: Salemba Medika

Poerwandari, E.K. (2005). Pendekatan Kualitatif Untuk Penelitian Perilaku Manusia. Jakarta: LPSP3, Fakultas Psikologi 
Indonesia.

Republika. (2013). Perempuan Lebih Rentan Tertular HIV.21 Agustus 2013.http://www.republika.co.id

Ridwan E, dkk (2013). Hambatan Terhadap Perilaku Pencegahan HIV dan AIDS pada pasangan ODHA Serodiskordan di Kota Makasar.Makassar: $\quad$ FKM Universitas Hasanudin.

Setiadi (2008). Konsep dan Proses Keperawatan keluarga. Yogyakarta: Graha Ilmu.

Setyoadi (2012). Strategi Pelayanan Keperawatan bagi Penderita AIDS. Yogyakarta: Graha Ilmu.

Siregar, N dkk. (2012). Faktor - faktor yang Mempengaruhi Perilaku Seksual Narapidana Remaja Pria di Lembaga Pemasyarakatan Kelas II B Balige Kabupaten Toba Samosir Tahun 2012. Skripsi FKM USU: tidak dipublikasikan

SPIRITIA (2009). Lembaran Informasi Tentang HIV dan AIDS untuk Orang yang Hidup dengan HIV dan AIDS (Odha). The Ford Foundation \& Australian Government AusAID.

Streubert, H.J., \& Carpenter, D.R. (2003). Qualitative research in nursing: Advancing the humanistic imperative. $3^{\text {rd }}$ ed. Philadelphia: Lippincot William Wilkins.

Sudiharto (2007). Asuhan Keperawatan Keluarga dengan Pendekatan Keperawatan Transkultural. Jakarta: EGC.

Sugiyono (2008). Metode Penelitian Kuantitatif Kualitatif dan $R \& D$. Bandung: Alfabeta

Tempo.com. (2012). Perilaku Seks Beresiko Jadi Sebab Tingginya HIV. 23 Juli 2012. http://www.aidsindonesia.or.id
Toto (2013). Seks Liar, Batasan Pun Dilanggar!. 08 April 2013. Surabaya post. http://www.surabayapost.co.id

Universitas Indonesia (2009), Pedoman Teknis Penulisan Tugas Akhir Mahasiswa universitas Indonesia.

Warto dkk (2007). Ujicoba Model Pelayanan Sosial Penyandang HIV dan AIDS.Yogyakarta: Departemen Sosial RI.

Windhu, (2009).Disfungsi Seksual : Tinjauan Fisiologis dan Patologis Terhadap Seksualitas. Yogyakarta :C.V Andi Offset.

Yurisa W (2008). Etika Penelitian Kesehatan. Faculty of MedicineUniversity of Riau. http://yayanakhyar.wordpress.co $\underline{\mathrm{m}}$ 